\title{
EFFECTIVENESS OF CARDIAC WALKING ON BLOOD PRESSURE AMONG PATIENTS WITH HYPERTENSION AT A SELECTED HOSPITAL IN KANCHEEPURAM DISTRICT
}

\author{
PUNITHA JOSEPHINE S, CHANDRASEKHAR M
}

Department of Medical Surgical Nursing, Karpagavinayaga College of Nursing, Madhurantakam, Kancheepuram - 603 308, Tamil Nadu, India. Email: punirhythm2004@yahoo.co.in, chandumeesala999@gmail.com

Received: 16 January 2017, Revised and Accepted: 14 February 2017

\section{ABSTRACT}

Objective: Hypertension is a multifactorial disease and it is a common disorder worldwide. This study was conducted to identify the effectiveness of cardiac walking on blood pressure (BP) among patients with hypertension at a selected hospital in Kancheepuram district.

Methods: A quasi-experimental pre- and post-test with comparison group design was chosen for this study. Using purposive sampling technique, a total of 50 samples were recruited for the study which included 25 each in study and comparison groups. Pre-test was done using a structured instrument that included demographic, biological, and clinical variables, and BP was measured by stethoscope and sphygmomanometer. Cardiac walking was implemented for the study group participants whereas comparison group participants were on routine care. Post-test was done for both the study and comparison group participants. Both descriptive and inferential statistics were used for the analysis.

Results: The paired t-test revealed the statistically significant difference between pre- and post-test systolic and diastolic BP within the study group participants at level $\mathrm{p}<0.001$ whereas there was no significant difference among comparison group participants. The independent $\mathrm{t}$-test unveiled the statistically significant difference between the study and comparison group participants in BP at level $p<0.001$.

Conclusion: These study findings implied that the simple measure cardiac walking is cost-effective to maintain the BP within normal limit for patients with hypertension throughout their survivorship.

Keywords: Hypertension, cardiac walking, blood pressure.

(c) 2017 The Authors. Published by Innovare Academic Sciences Pvt Ltd. This is an open access article under the CC BY license (http://creativecommons. org/licenses/by/4. 0/) DOI: http://dx.doi.org/10.22159/ajpcr.2017.v10i5.17125

\section{INTRODUCTION}

"Hypertension is a silent killer but preventable."

The current lifestyle pattern of human beings is assiduous and diligent to keep in pace with the tremendous changes in their work schedule. This mounts enormous pressure and creates health problems. In the contemporary world, one of the common lifestyle-related health problems is hypertension which is also known as high or raised blood pressure (BP). It is a major global public health issue. A combination of lifestyle factor increases the risk of non-communicable disorders, especially increases the resistance of blood flow through the arteries leading to high BP.

Globally, the overall prevalence of raised BP in adults aged 25 years and over was around 40\% in 2008 (World Health Organization [WHO]). The proportion of the world's population with high BP, or uncontrolled hypertension, fell modestly between 1980 and 2008 [1]. The study conducted by the Indian Council of Medical Research (2014) in Tamil Nadu, Maharashtra, Jharkhand, and Chandigarh unveiled that the prevalence of hypertension was highest in Tamil Nadu at $27.6 \%$, followed by Chandigarh at 25.8\%, Maharashtra at 25\%, and Jharkhand at $23 \%$. While overall, the prevalence of hypertension was more in urban areas than in rural areas [2]. According to the WHO (2012), hypertension is the number one cause of mortality in the world and it is a major risk factor for cardiac diseases and stroke [3]. The progressively higher BP leads to end-stage renal disease. Hence, to investigate the simple measure to reduce BP, a study was conducted with an objective of determination of the effect of cardiac walking on BP among patients with hypertension.

\section{METHODS}

A quantitative research approach of quasi-experimental pre- and post-test with comparison group design was chosen for this study.
A total of 50 samples were recruited using purposive sampling technique which composed of 25 each in study $(n=25)$ and comparison groups $(n=25)$. Ethical approval was obtained from the Institutional Ethical Committee from the selected hospital at Kancheepuram district, and informed consent was obtained from all the samples. Patients who were male and diagnosed to have hypertension, who were ambulatory and aged between 35 and 45 years, and able to talk and understand Tamil or English were included for the study.

Patients who had impaired physical mobility in the lower limbs and unable to walk, mentally challenged, disoriented, and unable to follow the instructions, who were diagnosed to have congestive cardiac failure, valvular disorders, and cardiomyopathy, who had edema in the lower limb, and who were regularly practicing yoga and/or exercises were excluded from the study.

The structured tools included were Part I, II, III, and IV.

- Part I: Demographic variables which were obtained by interview method. It was designed with nine items that included age, marital status, religion, education, occupation, and dietary pattern, history of smoking, history of alcoholism, and history of chewing tobacco

- Part II: Biological variables were obtained by anthropometric measurements and interview method. It encompassed height, weight, body mass index, waist circumference, and sleeping pattern

- Part III: Clinical variables were collected by clinical record survey which included comorbidity, time since diagnosis, name of the antihypertensive medication, duration of treatment, blood glucose level, and total cholesterol level

- Part IV: Consisted of assessment of BP (mmHg) using stethoscope and sphygmomanometer and classification of BP as shown in Table 1. 
Data collection procedure

The data were obtained using structured instrument Part I, II, III, and IV in pre-test and only Part IV was obtained in post-test for both the study and comparison group participants. The study design was divided into pre-test on day 1 for study and comparison groups, cardiac walking for 7 days with routine treatment for study group, only routine treatment for comparison group, and post-test on day 8 for both the group participants. Cardiac walking was taught for the study group participants that encompassed three phases, namely,

- Phase I: Warm up - It involved 5-10 minutes of low intensity walking

- $\quad$ Phase II: 10-15 minutes of moderate intensity walking

- Phase III: Cool down, this included 5-10 minutes of low intensity walking.

The study group participants were given audio-visual session regarding general information about hypertension (definition, causes/risk factors, normal systolic and diastolic BP values, management, and complications) and demonstration of cardiac walking by the investigator after pre-test on day 1 , whereas comparison group participants were on routine care that was only antihypertensive medications. Post-test was done for both group participants on day 8 .

\section{Statistical analysis}

The data were analyzed by Statistical Package for Social Sciences version 16. The paired t- and independent t-tests were computed to find the difference in BP within and between the study and comparison groups, respectively.

The hypothesis " $\mathrm{H}_{1}$ : There is a significant difference in the systolic and diastolic BP among patients with hypertension who had subjected to cardiac walking than those who had not" was tested in this study.

\section{RESULTS}

Age-wise distribution showed that $8(32 \%)$ participants in study and comparison groups each were aged between 35 and 37 years whereas 7 (28\%) participants in each group were aged between 38 and 40 years. Out of 50 samples, 12 (48\%) study group participants had the habit of chewing tobacco against 8 (32\%) in comparison group (Table 2).

With respect to the body mass index classification, 12 (48\%) participants in study group and 17 (68\%) in comparison group were classified as overweight. Out of 25 participants each in study and comparison groups, 9 (36\%) and 16 (64\%) participants, respectively, had the waist circumference ranging from 85.1 to $90 \mathrm{~cm}$ (Table 3).

With reference to the total cholesterol, 13 (52\%) study group participants had the value between 191 and $200 \mathrm{mg} / \mathrm{dl}$ against comparison group participants of 15 (60\%) (Table 4).

The distribution of level of BP in pre- and post-test among study group participants revealed that all the $25(100 \%)$ study group participants had Stage 1 systolic and diastolic hypertension in the pre-test, whereas in post-test, 22 (88\%) and 25 (100\%) participants had pre-hypertension systolic and pre-hypertension diastolic, respectively. Only 1 (4\%) participant had Stage 1 hypertension systolic in the post-test (Table 5).

The distribution of level of BP in the pre- and post-test among comparison group showed that all the $25(100 \%)$ comparison group participants had the Stage 1 systolic and diastolic hypertension in the pre-test, whereas in the post-test, $23(92 \%)$ had Stage 1 systolic and diastolic hypertension. About 2 (8\%) participants progressed to Stage 2 systolic and diastolic hypertension in the post-test (Table 6).

The comparison of pre- and post-test systolic and diastolic BP within the study group depicted statistically significant difference at $\mathrm{p}<0.001$. The comparison of pre- and post-test systolic and diastolic BP within comparison group illustrated no statistically significant difference (Table 7).
Table 1: Classification of BP

\begin{tabular}{lll}
\hline Classification of BP & Systolic $(\mathbf{m m H g})$ & Diastolic $(\mathbf{m m H g})$ \\
\hline Normal & $<120$ & And $<80$ \\
Pre-hypertension & $120-139$ & Or $80-89$ \\
Stage 1 hypertension & $140-159$ & Or $90-99$ \\
Stage 2 hypertension & $\geq 160$ & Or $\geq 100$ \\
\hline
\end{tabular}

BP: Blood pressure

Table 2: Distribution of demographic variables among study and comparison groups $(\mathrm{N}=50)$

\begin{tabular}{|c|c|c|c|}
\hline \multirow[t]{2}{*}{ S.No } & \multirow[t]{2}{*}{ Demographic variables } & \multicolumn{2}{|l|}{ N (\%) } \\
\hline & & $\begin{array}{l}\text { Study } \\
\text { group }\end{array}$ & $\begin{array}{l}\text { Comparison } \\
\text { group }\end{array}$ \\
\hline \multirow[t]{5}{*}{1} & Age (years) & & \\
\hline & $35-37$ & $8(32.00)$ & $8(32.00)$ \\
\hline & $38-40$ & $7(28.00)$ & $7(28.00)$ \\
\hline & $41-43$ & $7(28.00)$ & $6(24.00)$ \\
\hline & $44-45$ & $3(12.00)$ & $4(16.00)$ \\
\hline \multirow[t]{3}{*}{2} & Marital status & & \\
\hline & Married & $25(100.00)$ & $25(100.00)$ \\
\hline & Unmarried & $0(0)$ & $0(0)$ \\
\hline \multirow[t]{4}{*}{3} & Religion & & \\
\hline & Christian & $6(24.00)$ & $5(20.00)$ \\
\hline & Hindu & $15(60.00)$ & $16(64.00)$ \\
\hline & Muslim & $4(16.00)$ & $4(16.00)$ \\
\hline \multirow[t]{6}{*}{4} & Educational status & & \\
\hline & Primary school & $12(48.00)$ & $8(32.00)$ \\
\hline & Middle school & $3(12.00)$ & $7(28.00)$ \\
\hline & High school & $3(12.00)$ & $8(32.00)$ \\
\hline & Higher secondary school & $4(16.00)$ & $1(4.00)$ \\
\hline & Undergraduate & $3(12.00)$ & $1(4.00)$ \\
\hline \multirow[t]{6}{*}{5} & Occupation & & \\
\hline & Labor & $9(36.00)$ & $11(44.00)$ \\
\hline & Farmer & $7(28.00)$ & $5(20.00)$ \\
\hline & Government employee & $2(8.00)$ & $1(4.00)$ \\
\hline & Private employee & $4(16.00)$ & $4(16.00)$ \\
\hline & Business & $3(12.00)$ & $4(16.00)$ \\
\hline \multirow[t]{4}{*}{6} & Dietary habits & & \\
\hline & Vegetarian & $0(0)$ & $0(0)$ \\
\hline & Non-vegetarian & $0(0)$ & $0(0)$ \\
\hline & Mixed & $25(100.00)$ & $25(100.00)$ \\
\hline \multirow[t]{3}{*}{7} & History of smoking & & \\
\hline & Yes & $15(60.00)$ & $13(52.00)$ \\
\hline & No & $10(40.00)$ & $12(48.00)$ \\
\hline \multirow[t]{3}{*}{8} & History of alcoholism & & \\
\hline & Yes & $14(56.00)$ & $11(44.00)$ \\
\hline & No & $11(44.00)$ & $14(56.00)$ \\
\hline \multirow[t]{3}{*}{9} & $\begin{array}{l}\text { History of chewing } \\
\text { tobacco }\end{array}$ & & \\
\hline & Yes & $12(48.00)$ & $8(32.00)$ \\
\hline & No & $13(52.00)$ & $17(68.00)$ \\
\hline
\end{tabular}

The comparison of post-test systolic and diastolic BP between study and comparison groups inferred that there was a statistically significant difference at a level of $\mathrm{p}<0.001$ (Table 8).

\section{DISCUSSION}

Hypertension is the common disorder worldwide affecting larger population. The mortality and morbidity rate of patients with hypertension are steadily increasing and pose the greatest threat to the health-care system.

The distribution of level of BP in pre-test unveiled that all 25 (100\%) participants each in study and comparison groups had Stage 1 systolic and diastolic hypertension in the pre-test, whereas in the post-test, $22(88 \%)$ study group participants had progressed to pre-hypertension 
Table 3: Distribution of biological variables among study and comparison groups $(\mathrm{N}=50)$

\begin{tabular}{llll}
\hline S.No & Biological variables & N (\%) & \\
\cline { 3 - 4 } & & $\begin{array}{l}\text { Study } \\
\text { group }\end{array}$ & $\begin{array}{l}\text { Comparison } \\
\text { group }\end{array}$ \\
\hline 1 & Body mass index $\left(\mathrm{kg} / \mathrm{m}^{2}\right)$ & & \\
& Underweight $(<19)$ & $0(0)$ & $0(0)$ \\
Ideal weight $(19.1-25)$ & $0(0)$ & $3(12)$ \\
Overweight $(25.1-30)$ & $12(48)$ & $17(68)$ \\
& Obese $(30.1-35)$ & $12(48)$ & $4(16)$ \\
& Severe obese $(35.1-40)$ & $1(4)$ & $0(0)$ \\
& Morbid obese $(>40)$ & $0(0)$ & $1(4)$ \\
& Duration of sleep (hours/day) & & \\
& $4-5$ & $2(8)$ & $0(0)$ \\
& $6-7$ & $9(36)$ & $7(28)$ \\
& $8-9$ & $9(36)$ & $7(28)$ \\
& More than 9 & $5(20)$ & $11(44)$ \\
& Waist circumference $(\mathrm{cm})$ & & \\
$70-75$ & $0(0)$ & $4(16)$ \\
& $75.1-80$ & $7(28)$ & $1(4)$ \\
& $80.1-85$ & $8(32)$ & $4(16)$ \\
& $85.1-90$ & $9(36)$ & $16(64)$ \\
& $90.1-95$ & $1(4)$ & $0(0)$ \\
& & &
\end{tabular}

Table 4: Distribution of clinical variables among study and comparison groups $(\mathrm{N}=50)$

\begin{tabular}{|c|c|c|c|}
\hline \multirow[t]{2}{*}{ S.No } & \multirow[t]{2}{*}{ Clinical variables } & \multicolumn{2}{|l|}{ N (\%) } \\
\hline & & $\begin{array}{l}\text { Study } \\
\text { group }\end{array}$ & $\begin{array}{l}\text { Comparison } \\
\text { group }\end{array}$ \\
\hline \multirow[t]{4}{*}{1} & Comorbidity & & \\
\hline & Diabetes mellitus & $11(44)$ & $10(40)$ \\
\hline & Osteoarthritis & $2(8)$ & $5(20)$ \\
\hline & Hypothyroidism & $12(48)$ & $10(40)$ \\
\hline \multirow[t]{4}{*}{2} & Time since diagnosis (month) & & \\
\hline & $1-10$ & $8(32)$ & $8(32)$ \\
\hline & $11-20$ & $14(56)$ & $16(64)$ \\
\hline & $21-30$ & $3(12)$ & $1(4)$ \\
\hline \multirow[t]{4}{*}{3} & Anti-hypertensive medication & & \\
\hline & Atenolol & $10(40)$ & $11(44)$ \\
\hline & Amlong & $11(44)$ & $12(48)$ \\
\hline & Propranolol & $4(16)$ & $2(8)$ \\
\hline \multirow[t]{4}{*}{4} & Duration of treatment (months) & & \\
\hline & $1-10$ & $8(32)$ & $8(32)$ \\
\hline & $11-20$ & $14(56)$ & $16(64)$ \\
\hline & $21-30$ & $3(12)$ & $1(4)$ \\
\hline \multirow[t]{6}{*}{5} & Random blood glucose (mgs/dl) & & \\
\hline & $100-120$ & $14(56)$ & $15(60)$ \\
\hline & $121-140$ & $5(20)$ & $6(24)$ \\
\hline & $141-160$ & $1(4)$ & $0(0)$ \\
\hline & $161-180$ & $5(20)$ & $3(12)$ \\
\hline & $181-200$ & $0(0)$ & $1(4)$ \\
\hline \multirow[t]{4}{*}{6} & Total cholesterol (mg/dl) & & \\
\hline & $170-180$ & $2(8)$ & $1(4)$ \\
\hline & $181-190$ & $10(40)$ & $9(36)$ \\
\hline & $191-200$ & $13(52)$ & $15(60)$ \\
\hline
\end{tabular}

systolic and 2 (8\%) had normal BP. All 25 (100\%) study group participants had progressed from Stage 1 hypertension-diastolic in the pre-test to pre-hypertension diastolic in the post-test.

Out of $25(100 \%)$ comparison group participants, 2 (8\%) had progressed to Stage 2 hypertension in terms of both systolic and diastolic BP, from Stage 1 hypertension, whereas majority of 23 (92\%) participants were on the same level of Stage 1 hypertension in the posttest. This emphasized that non-pharmacological measure of cardiac walking reduced the BP in spite of antihypertensive medications among study group participants because both study and comparison group
Table 5: Distribution of level of BP in pre- and post-test among study group $(\mathrm{N}=25)$

\begin{tabular}{|c|c|c|c|c|c|}
\hline \multirow[t]{3}{*}{ S.No } & \multirow{3}{*}{$\begin{array}{l}\text { Level of } \\
\text { BP (mmHg) }\end{array}$} & \multicolumn{4}{|c|}{ Study group N (\%) } \\
\hline & & \multicolumn{2}{|l|}{ Pre-test } & \multicolumn{2}{|c|}{ Post-test } \\
\hline & & Systolic & Diastolic & Systolic & Diastolic \\
\hline 1 & Normal & $0(0)$ & $0(0)$ & $2(8)$ & $0(0)$ \\
\hline 2 & Pre-hypertension & $0(0)$ & $0(0)$ & $22(88)$ & $25(100)$ \\
\hline 3 & $\begin{array}{l}\text { Stage-1 } \\
\text { hypertension }\end{array}$ & $25(100)$ & $25(100)$ & $1(4)$ & $0(0)$ \\
\hline 4 & $\begin{array}{l}\text { Stage- } 2 \\
\text { hypertension }\end{array}$ & $0(0)$ & $0(0)$ & $0(0)$ & $0(0)$ \\
\hline
\end{tabular}

Table 6: Distribution of level of BP in pre- and post-test among comparison group $(\mathrm{N}=25)$

\begin{tabular}{llllll}
\hline S.No & $\begin{array}{l}\text { Level of } \\
\text { BP (mmHg) }\end{array}$ & \multicolumn{3}{l}{ Comparison group N (\%) } \\
\cline { 3 - 4 } & & \multicolumn{2}{c}{ Pre-test } & & \multicolumn{2}{c}{ Post-test } \\
\cline { 3 - 4 } & & Systolic & Diastolic & Systolic & Diastolic \\
\hline 1 & Normal & $0(0)$ & $0(0)$ & $0(0)$ & $0(0)$ \\
2 & Hypertension & $0(0)$ & $0(0)$ & $0(0)$ & $0(0)$ \\
3 & $\begin{array}{l}\text { Stage-1 } \\
\text { hypertension }\end{array}$ & $25(100)$ & $25(100)$ & $23(92)$ & $23(92)$ \\
4 & $\begin{array}{l}\text { Stage-2 } \\
\text { hypertension }\end{array}$ & $0(0)$ & $0(0)$ & $2(8)$ & $2(8)$ \\
\hline
\end{tabular}

BP: Blood pressure

participants received antihypertensive medications. Since cardiac walking is a simple measure, patients with hypertension must be motivated to practice regularly.

The post-test disclosed that majority of 22 (88\%) and 25 (100\%) study group participants had pre-hypertension of systolic and diastolic BP, respectively, in contrast to 23 (92\%) comparison group participants whose BP was classified under Stage 1 hypertension of both systolic and diastolic BP. This proved that cardiac walking had reduced the BP among study group. The study group participants had taken antihypertensive drugs and also practiced cardiac walking whereas comparison group participants had taken only antihypertensive drugs without any nonpharmacological measures to reduce BP. These findings highlight the importance of regular cardiac walking among patients with hypertension. These findings are substantiated by the study conducted by Lima et al. which revealed that there were immediate $14 \mathrm{mmHg}$ and $12 \mathrm{mmHg}$ reduction in systolic $\mathrm{BP}$ and $4 \mathrm{mmHg}$ in diastolic BP after the exercise session for 5 days, which were statistically significant at $\mathrm{p}<0.05$ and $\mathrm{p}<0.01$, respectively [4]. Further, the above findings were supported by the study conducted by Warner and Louis on the effect of 30 minutes walking on BP for 5 days a week. The result showed the significant reduction of systolic BP $(\mathrm{p}<0.01)$ [5].

The paired t-test value on comparison of pre- and post-test scores of systolic and diastolic BPs within the study group revealed statistically significant difference at level $\mathrm{p}<0.001$, whereas in comparison group, significant difference was not elicited. These findings were further supported by the independent t-test, on comparison of post-test systolic and diastolic BP between study group and comparison group, which disclosed the statistically significant difference at a level of $\mathrm{p}<0.001$. The mean value of post-test systolic BP was $129.36 \mathrm{mmHg}$ among study group participants, whereas among comparison group, it was $142.36 \mathrm{mmHg}$. The mean value of post-test diastolic BP was $82.24 \mathrm{mmHg}$ among study group participants, but it was $91.16 \mathrm{mmHg}$ among comparison group participants. These differences in the mean value of systolic and diastolic BP were due to the effect of cardiac walking done by the study group participants. 
Table 7: Comparison of pre- and post-test $\mathrm{BP}$ within study and comparison groups $(\mathrm{N}=50)$

\begin{tabular}{|c|c|c|c|c|c|}
\hline \multirow[t]{2}{*}{ S.No } & \multirow[t]{2}{*}{ Observation } & \multicolumn{2}{|l|}{ Study group } & \multicolumn{2}{|l|}{ Comparison group } \\
\hline & & Mean \pm standard deviation & $\begin{array}{l}\text { Paired " } t \text { " value and } \\
p \text { value }\end{array}$ & Mean \pm standard deviation & $\begin{array}{l}\text { Paired " } t \text { " value and } \\
p \text { value }\end{array}$ \\
\hline 1 & Pre-test systolic (mmHg) & $142.08 \pm 2.98$ & $\begin{array}{l}8.458^{* * *} \\
\mathrm{p}=0.000\end{array}$ & $141.40 \pm 2.50$ & $\begin{array}{l}0.880 \\
p=0.388\end{array}$ \\
\hline 2 & Post-test systolic (mmHg) & $129.36 \pm 6.67$ & SS & $140.96 \pm 1.01$ & NS \\
\hline 3 & Pre-test systolic (mmHg) & $90.72 \pm 1.42$ & $\begin{array}{l}17.060^{* * *} \\
\mathrm{p}=0.000\end{array}$ & $90.88 \pm 1.64$ & $\begin{array}{l}1.429 \\
p=0.166\end{array}$ \\
\hline 4 & Post-test diastolic (mmHg) & $82.24 \pm 1.85$ & SS & $90.32 \pm 1.10$ & NS \\
\hline
\end{tabular}

***Significant at p<0.001, NS: Not significant, SS: Statistically significant, BP: Blood pressure

Table 8: Comparison of post-test BP between study and comparison groups $(\mathrm{N}=50)$

\begin{tabular}{|c|c|c|c|c|}
\hline \multirow[t]{2}{*}{ S.No } & \multirow{2}{*}{ Observation } & \multirow{2}{*}{$\begin{array}{l}\text { Study group } \\
\begin{array}{l}\text { Mean } \pm \text { standard } \\
\text { deviation }\end{array}\end{array}$} & \multirow{2}{*}{$\begin{array}{l}\text { Comparison } \\
\text { group } \\
\begin{array}{l}\text { Mean士standard } \\
\text { deviation }\end{array} \\
\end{array}$} & \multirow{2}{*}{$\begin{array}{l}\text { "t" value } \\
\text { and p value }\end{array}$} \\
\hline & & & & \\
\hline 1 & $\begin{array}{l}\text { Post-test } \\
\text { systolic } \\
(\mathrm{mmHg})\end{array}$ & $129.36 \pm 6.67$ & $142.36 \pm 4.60$ & $\begin{array}{l}-8.012^{* * *} \\
\mathrm{p}=0.000 \\
\mathrm{SS}\end{array}$ \\
\hline 2 & $\begin{array}{l}\text { Post-test } \\
\text { diastolic } \\
(\mathrm{mmHg})\end{array}$ & $82.24 \pm 1.85$ & $91.16 \pm 3.53$ & $\begin{array}{l}-11.180^{* * *} \\
\mathrm{p}=0.000 \\
\mathrm{SS}\end{array}$ \\
\hline
\end{tabular}

In addition, the findings of this study were supported by the study conducted by Grassi et al. on the effectiveness of walking exercise program in controlling the BP which revealed that, after walking, there was a mean reduction of $12 \mathrm{mmHg}(\mathrm{p}<0.0001)$ in systolic BP and $4 \mathrm{mmHg}$ in diastolic BP in women $(\mathrm{p}<0.005)$ [6].Thus it affirms that walking exercise reduces blood pressure among patients with hypertension.[6].

Many studies have proved the effectiveness of non-pharmacological interventions on BP among patients with hypertension. A research study conducted by Kandasamy et al. regarding the impact of education about lifestyle modification on BP unveiled that there was a statistically significant reduction in the BP which also improved the quality of life among patients with hypertension [7]. Another study conducted by Devi and Pamba disclosed that Bamboo shoots are very effective in reducing BP among patients with hypertension [8]. This study findings are substantiated by the various research findings as quoted above and proved that simple, cost-effective intervention - cardiac walking - is effective in reducing BP among patients with hypertension.

Hence, $\mathrm{H}_{1}$ "There is a significant difference in the systolic and diastolic BP among patients with hypertension who had subjected to cardiac walking than those who had not" is accepted. In addition to the above findings, hypertension causes complication and reduces the life expectancy. This is substantiated by the study conducted by Urrutia et al. which revealed that males with hypertension, diabetes mellitus, family history of cardiovascular diseases, and history of smoking have higher risk for heart attack $(n=203$ [62.08\%]) than females, which is fatal [9]. Similarly, the uncontrolled BP patients were more likely to be males (odds ratio=5.03; 95\% confidence interval: $2.86-8.86 ; \mathrm{p}<0.001$ ) according to the study findings by Soubra et al. [10]. These findings insist the importance of non-pharmacological measures to reduce BP among patients with hypertension.

\section{CONCLUSION}

Cardiac walking is very effective and significantly reduces and maintains BP within normal limit among patients with hypertension. Over to this, it is a simple, cost-effective measure to maintain normal BP along with pharmacological measures. Cardiac walking is an easiest home remedy which can be practiced by all patients with hypertension and this will prevent the complications related to hypertension.

\section{REFERENCES}

1. Available from: http://www.who.int/gho/ncd/risk_factors/blood pressure prevalence text/en/2008

2. Available from: ${ }^{-}$http://www.icmr.nic.in/.../indiab/Executive $\% 20$ summary_INDIAB_Phase\%20I.pdf 2014

3. Available from: http://www.who.int/gho/ncd/risk factors/blood pressure_prevalence_text/en/2012.

4. Lima LG, Moriguti JC, Ferriolli E, Lima NK. Effect of a single session of aerobic walking exercise on arterial pressure in community-living elderly individuals. Hypertens Res 2012;35(4):457-62.

5. Warner J, Louis MD. Effect of 30 minutes walking on blood pressure. J Epidemiol Community Health BMJ 2013;61:778-83.

6. Grassi G, Serravalle G, Calhoun D. The effect of walking exercise daily for 30 minutes on blood pressure among patients with hypertension. Chest 2012;101 suppl 5:312-4.

7. Kandasamy K, Natarajan A, Rajagopal SS, Sebastian J, Konakalla M, Sam R, et al. Impact of pharmacist intervention in screening and education on blood pressure in a rural area in Southern India. Asian J Pharm Clin Res 2016;9(3):339-43.

8. Devi OJ, Pamba P. Antihypertensive activity of Bamboo shoot: A review. Asian J Pharm Clin Res 2015;8(1):46-7.

9. Urrutia JD, Razzcelle I, Mercado J, Baygan AV. Survival analysis for the risk of developing heart attack. Int $\mathrm{J}$ Pharm Pharm Sci 2016;8 Suppl 2:6-10.

10. Soubra L, Nureddin H, Omar AG, Saleh M. Factors associated with hypertension prevalence and control among Lebanese Type 2 diabetic patients. Int J Pharm Pharm Sci 2016;8(10):153-9. 